\title{
Study on laws of gas occurrence and emission of deep coal seam in
}

\section{Yaoqiao Coal Mine}

\author{
Gen-yin CHENG ${ }^{1,2}$, Yi-fei Zhou², LI-ming Qi $^{2}$, Shan FENG ${ }^{2}$ and Jian CAO ${ }^{2}$ \\ ${ }^{1}$ Department of Safety Training of North China Institute of Science and Technology Sanhe, Hebei \\ 065201, China \\ ${ }^{2}$ College of Safety Engineering North China Institute of Science and Technology Sanhe, Hebei \\ 065201,China
}

Key words: Gas content; Gas Emission; Laws of gas occurrence and emission

Abstract: To grasp the gas occurrence and emission laws of Yaoqiao deep coal mining area (West ten mining area and the second central mining area) in No.7 Coal Seam, the neural network is used to analyze the relationship and degree of influence factors between gas occurrence and gas content. We construct a prediction model of gas content to predict the gas content of the corresponding position and draw contour map of the gas content. We combine gas geological data of Yaoqiao coal mine and summarize the law of gas occurrence and emission to guide the work of gas prevention and control and enhance the prevention level of gas disaster.

\section{Introduction}

Coal seam gas control is a worldwide problem and China is one of the world's gas accident-prone countries. With the increase of mining depth, significant changes in mining conditions and natural environment have come. The phenomenon of highland stress, high gas, non-uniformity, low permeability and low intensity of coal appear. More and more serious gas even makes grade of gas a fundamental change. Original high gas coal mine and even in parts of mines of a small amount of gas began to appear mine dynamic[1]..

The geological data of Yaoqiao coal mine shows the presence of gas abnormal area in deep mining area. And its adjacent mine, such as Cuizhuang, Gaozhuang and Fucun all exist high gas coal mine areas. Some places even reached the critical value of gas outburst[5].

\section{Laws of gas occurrence and main influencing factors}

Laws of gas occurrence Looking for the law of gas occurrence requires a lot of gas data, but if all is measured, the quantity is big, cycle is long, and cost is high. Therefore, we must use the measured gas content and the factors of gas occurrence to analyze the relationship between the two. Then we can apply this relationship to unknown area and according to the factors of gas occurrence to predict gas content. At last we can increase the gas data and analyzes the law of gas occurrence. We can use active measurement method of gas pressure in underground coal seam and face drilling cinder analytic method to measure the date of gas content. Using neural network to further analyze the nonlinear relationship between various factors of gas occurrence and the gas content, we build prediction model and use geological parameters within the study area to predict gas parameters. The measured data are shown in table 1[6]. 
Table 1 Gas content determination results

\begin{tabular}{|c|c|c|c|c|c|c|c|}
\hline $\begin{array}{l}\text { Serial } \\
\text { number }\end{array}$ & Position & $\begin{array}{l}\text { Buried } \\
\text { depth }\end{array}$ & $\begin{array}{l}\text { Gas } \\
\text { content }\end{array}$ & $\begin{array}{l}\text { Serial } \\
\text { number }\end{array}$ & Position & $\begin{array}{l}\text { Buried } \\
\text { depth }\end{array}$ & Gas conten \\
\hline 1 & 7011A down pipe & 865 & 2.10 & 11 & \multirow{4}{*}{$\begin{array}{l}\text { 7011CDown } \\
\text { pipe Road }\end{array}$} & 855 & 1.96 \\
\hline 2 & Road & 865 & 2.28 & 12 & & 855 & 1.89 \\
\hline 3 & West ten coal & 877 & 2.46 & 13 & & 860 & 1.83 \\
\hline 4 & $\begin{array}{l}\text { exploration down } \\
50 \mathrm{~m}\end{array}$ & 877 & 2.38 & 14 & & 860 & 1.78 \\
\hline 5 & West ten coal & 925 & 2.68 & 15 & \multirow{2}{*}{$\begin{array}{l}\text { Central mining } \\
\text { area roadway } \\
\text { drainage }\end{array}$} & 875 & 1.52 \\
\hline 6 & $\begin{array}{l}\text { exploration } \\
\text { downhill } 200 \mathrm{~m}\end{array}$ & 925 & 2.76 & 16 & & 885 & 1.64 \\
\hline 7 & \multirow{2}{*}{-850 West Lane } & 855 & 2.54 & 17 & 7620 Material & 715 & 1.36 \\
\hline 8 & & 855 & 2.48 & 18 & Road & 720 & 1.42 \\
\hline 9 & Back to wind & 855 & 2.18 & 19 & Fall down the & 875 & 1.50 \\
\hline 10 & $\begin{array}{l}\text { down the West } \\
\text { Kowloon }\end{array}$ & 855 & 2.06 & 20 & $\begin{array}{l}\text { central mining } \\
\text { area }\end{array}$ & 865 & 1.48 \\
\hline
\end{tabular}

Through the prediction model of gas content, we predict the gas content of other parts of the study area. Predicted data are shown in table 2

Table 2 Prediction of gas content in coal seam

\begin{tabular}{cccccccc}
\hline Serial number & $\begin{array}{c}\text { thickness of } \\
\text { roof } \\
\text { mudstone }\end{array}$ & $\begin{array}{c}\text { thickness } \\
\text { of floor } \\
\text { mudstone }\end{array}$ & $\begin{array}{c}\text { Buried } \\
\text { depth }\end{array}$ & $\begin{array}{c}\text { Distance } \\
\text { from the } \\
\text { nearest fault }\end{array}$ & $\begin{array}{c}\text { Fault } \\
\text { throw }\end{array}$ & $\begin{array}{c}\text { Seam } \\
\text { thickness }\end{array}$ & $\begin{array}{c}\text { Gas } \\
\text { content }\end{array}$ \\
\hline 1 & 0.8 & 1.3 & 905 & 15 & 7 & 3.60 & 1.367 \\
2 & 1.1 & 2.1 & 925 & 20 & 13 & 3.74 & 1.433 \\
3 & 1.8 & 2.0 & 960 & 160 & 42 & 4.49 & 1.713 \\
4 & 0.9 & 1.4 & 910 & 60 & 6 & 3.44 & 1.365 \\
5 & 1.6 & 2.8 & 970 & 50 & 20 & 3.38 & 2.371 \\
6 & 1.9 & 3.3 & 960 & 20 & 25 & 3.80 & 2.731 \\
7 & 2.2 & 3.4 & 1010 & 50 & 15 & 4.44 & 2.657 \\
8 & 2.1 & 4.2 & 1035 & 100 & 13 & 4.28 & 2.693 \\
9 & 2.4 & 4.8 & 1115 & 25 & 5 & 4.36 & 2.748 \\
\hline
\end{tabular}

Through the neural network prediction model and the corresponding geological parameters to predict gas parameters, but the gas parameters are messy. It is very difficult to judge gas distribution parameter intuitive. Using mathematics software, measured data and gas prediction, we map the gas content contour map of west 10 mining area and the second central mining area. Respectively as shown in figure 2 and figure $3[6] .$. 


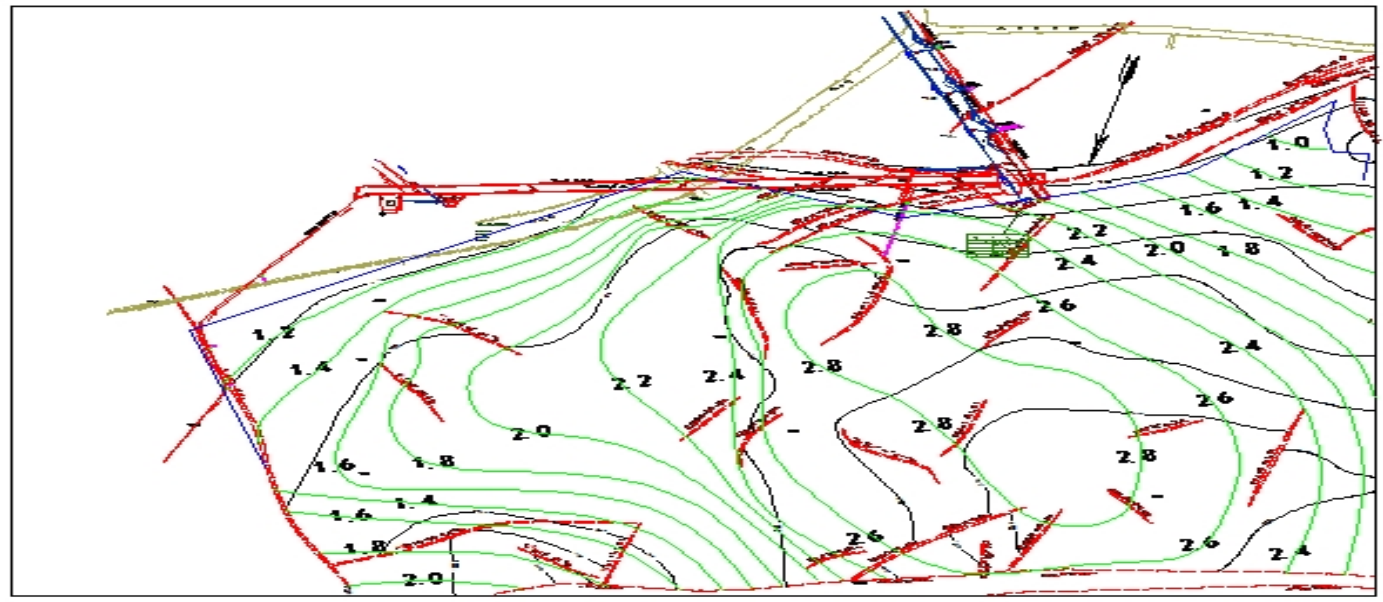

Figure 2 The gas content in the West ten mining area

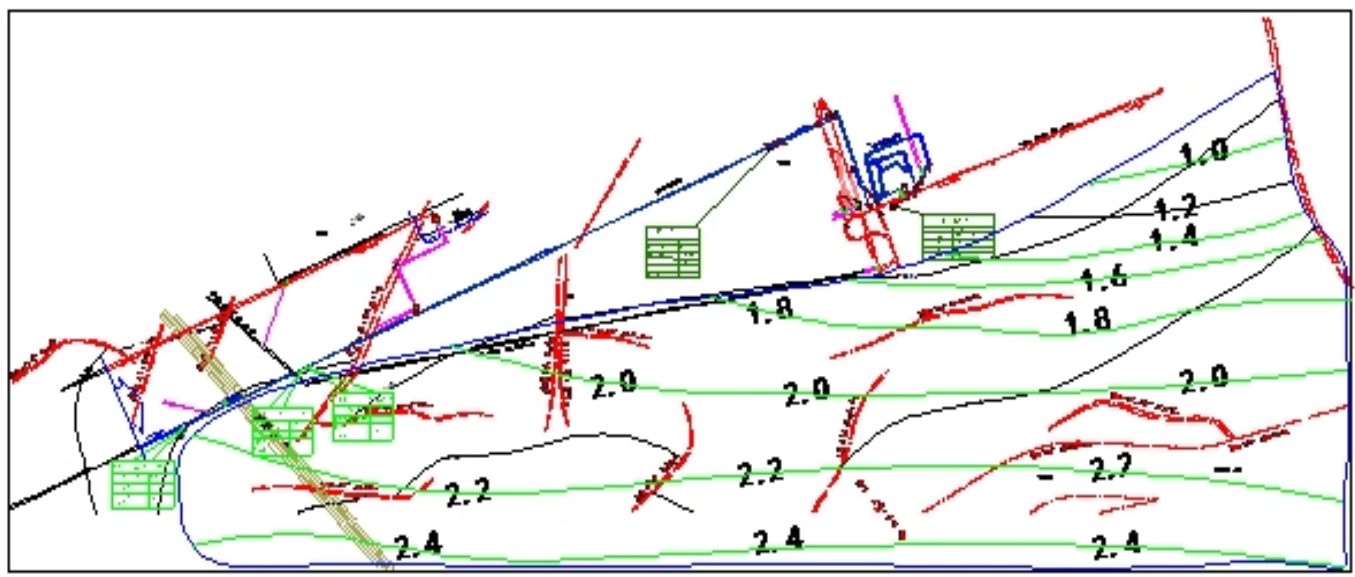

Figure 3 The gas content in the second central mining area

From the contour map of gas content in west ten mining area and the second central mining area, it can be seen that the local area is relatively high in the vicinity of the fault. Respectively, between the fault f298 and the fault f320, nearby faults f431, faults f349. Coal seam permeability of these areas is generally poor.

In the second central mining area, gas content rises with increasing mining depth, the law of occurrence is relatively simple. Gas content rises also with increasing depth of mining in ten mining area, but gas content is relatively low in ten west mining area, and the gas gradient is bigger[3]..

The main influencing factors For the study area of coal seam, the gas parameter is affected by many factors, such as the buried depth of coal seam, surrounding rock permeability, geological structure and so on. These factors have different impacts on gas occurrence. There are main control factors and secondary control factors.

Use computers to analyze the influence factors of gas parameters with neural network, specific data as shown in table 3.

Table 3 Influence Factors of coal seam gas parameters

\begin{tabular}{ccccc}
\hline Parameter & $\begin{array}{c}\text { thickness of Roof and } \\
\text { floor mudstone }\end{array}$ & Depth & Fault & $\begin{array}{c}\text { thickness of } \\
\text { coal seam }\end{array}$ \\
\hline \multirow{2}{*}{ Gas content } & $\begin{array}{c}0.409(0.162 \text { and } \\
0.247)\end{array}$ & 0.204 & $0.238(0.187$ and & 0.149 \\
\hline
\end{tabular}

According to table 3 , the main controlling factors of the coal seam gas parameters in the study area 
are the fault and the thickness of roof and floor mudstone, the depth and thickness of coal seam is in a secondary position.

\section{Gas emission laws}

According to the appraisal data of mine gas level, the project team collected the gas emission data from the partial mining face.

Table 4 Data sheet of Gas emission in coal mining face

\begin{tabular}{|c|c|c|c|c|c|}
\hline Serial & Face & \multicolumn{2}{|c|}{ Relative gas emission quantity } & \multirow[t]{2}{*}{$\left(\mathrm{m}^{3} / \mathrm{t}\right)$} & \multirow[t]{2}{*}{ Mining depth $(\mathrm{m})$} \\
\hline \multirow[b]{2}{*}{1} & \multirow[b]{2}{*}{7717 Face } & Methane & 0.0007 & & \\
\hline & & $\begin{array}{l}\text { Carbon } \\
\text { dioxide }\end{array}$ & 0.0484 & 0.0491 & 435 \\
\hline \multirow[b]{2}{*}{2} & \multirow[b]{2}{*}{7521 Face } & Methane & 0.0031 & \multirow[b]{2}{*}{0.1578} & \multirow[b]{2}{*}{635} \\
\hline & & $\begin{array}{l}\text { Carbon } \\
\text { dioxide }\end{array}$ & 0.1547 & & \\
\hline \multirow[b]{2}{*}{3} & \multirow[b]{2}{*}{7541 Face } & Methane & 0.0073 & \multirow[b]{2}{*}{0.3081} & \multirow[b]{2}{*}{685} \\
\hline & & $\begin{array}{l}\text { Carbon } \\
\text { dioxide }\end{array}$ & 0.3728 & & \\
\hline \multirow[b]{2}{*}{4} & \multirow[b]{2}{*}{7011 Face } & Methane & 0.0031 & \multirow[b]{2}{*}{0.6545} & \multirow[b]{2}{*}{835} \\
\hline & & $\begin{array}{l}\text { Carbon } \\
\text { dioxide }\end{array}$ & 0.6514 & & \\
\hline
\end{tabular}

Table 5 Data sheet of Gas emission in heading face

\begin{tabular}{|c|c|c|c|c|c|c|}
\hline \multirow{2}{*}{$\begin{array}{l}\text { From } \\
\text { table, } \\
\text { be }\end{array}$} & \multirow[t]{2}{*}{ Serial number } & \multirow[t]{2}{*}{ Face } & \multicolumn{3}{|c|}{ Relative gas emission quantity $\left(\mathrm{m}^{3} / \mathrm{t}\right)$} & \multirow[t]{2}{*}{$\begin{array}{l}\text { Mining } \\
\text { depth }(\mathrm{m})\end{array}$} \\
\hline & & & Methane & 0.0034 & & \\
\hline that & 1 & 7707 heading face & $\begin{array}{l}\text { Carbon } \\
\text { dioxide }\end{array}$ & 0.1563 & 0.1597 & 285 \\
\hline & & & Methane & 0.0092 & & \\
\hline & 2 & 7502 heading face & $\begin{array}{l}\text { Carbon } \\
\text { dioxide }\end{array}$ & 0.7196 & 0.5830 & 335 \\
\hline & & & Methane & 0.0310 & & \\
\hline & 3 & 7011 heading face & $\begin{array}{l}\text { Carbon } \\
\text { dioxide }\end{array}$ & 1.0955 & 1.1265 & 835 \\
\hline
\end{tabular}

relative gas emission is relatively small, which is far lower than the minimum critical value of the high gas coal mine $10 \mathrm{~m}^{3} / \mathrm{t}$. To show more clearly relationship between gas emission quantity and mining depth, we use mining depth as dependent variable and gas emission quantity as the independent variables. At last we analyze the data of table 4 and draw the following relationship:

$$
\mathrm{y}=0.0015 \mathrm{x}-0.6714
$$

We can calculate the $\mathrm{R}_{2}=0.8693$ and indicate a good correlation.

In the same way, the relationship between the quantity of relative gas emission of $Y$ and the depth of 
$\mathrm{X}$ is also available:

$$
\mathrm{y}=0.0015 \mathrm{x}-0.0976
$$

We can calculate the $\mathrm{R}_{2}=0.8695$ and indicate a good correlation.

From (1) and (2) coal seam gradient of the relative gas emission can be calculated as $0.15\left(\mathrm{~m}^{3} / \mathrm{t}\right) / \mathrm{hm}$. When the mining depth increases $100 \mathrm{~m}$, the relative gas emission increases $0.15 \mathrm{~m}^{3} / \mathrm{t}$. It shows that the coal seam gradient of relative gas emission is small.

According to the "2014 gas level identification report of Yaoiao coal mine ", the relative gas emission rate of the mine is $\mathrm{Q}_{\mathrm{CH} 4}=0.0049 \mathrm{~m}^{3} / \mathrm{t}, \mathrm{Q}_{\mathrm{CO} 2}=0.6191 \mathrm{~m} 3 / \mathrm{t}$; The absolute amount of mine gas emission is $\mathrm{Q}_{\mathrm{CH} 4}=0.0453 \mathrm{~m} 3 / \mathrm{min}, \mathrm{Q}_{\mathrm{CO} 2}=5.7360 \mathrm{~m} 3 / \mathrm{min}$. So the grade of mine is gas coal mine.

The amount of gas emission in coal mining face is $0.01382 \mathrm{~m}^{3} / \mathrm{min}$; the amount of gas emission in heading face is $0.0027 \mathrm{~m}^{3} / \mathrm{min}$; the amount of gas emission in goaf is $0.02618 \mathrm{~m}^{3} / \mathrm{min}$. Analyzing the source of the whole mine gas emission, we can know that mine gas emission is mainly from goaf; coal mining working face, heading face, and goaf respectively account for $32.32 \%, 6.32 \%$ and $61.36 \%$.

\section{Conclusion}

(1) Using the neural network to analyze the relationship between gas content and the various geological parameters, through sample training, Yaoqiao coal gas content prediction model is established. According to the parts of the geological parameters, we predict the gas content in certain region successfully. Based on measuring and predicting gas data, we draw the contour map of gas content in second mining area and ten mining area.

(2) Gas content of the deep area in Yaoqiao coal is generally not high, and the relationship with the buried depth of coal seam is positively correlated. But near the fault, the gas content is high. The main controlling factors of gas content is fault and the thickness of roof and floor mudstone, and the depth of coal seam and the thickness is in a secondary position.

(3) According to actual situation and the requirement of "coal mine gas drainage standards interim provisions", it is suggested that the gas treatment of the mine should be dominated by ventilation, and may be appropriate with the pumping technology.

\section{Acknowledgement}

The authors thank the support of the National Natural Science Foundation provided to this project (No. U1361130).

\section{Reference}

[1] State administration of work safety, State administration of coal mine safety. Coal Mine Safety Regulations [M]. Beijing: China coal industry publishing house, 2011.

[2] State administration of work safety, State administration of coal mine safety. Provisions for the prevention of coal and gas outburst [M]. Beijing: China coal industry publishing house, 2011.

[3] Zhao Li, Zeng Yong, Lv Qian.Study on gas occurrence and gas emission in coal mine[J]. Coal engineering 2011(3): 84 86.

[4] Hu Qianting, Zou Yinhui, Wen Guangcai.Prediction of gas content in New Technology[J]. 
Journal of coal 2007,32(3): 276 280.

[5] Chou Haisheng, Zhang Baoquan.Determination of gas content in coal seam by gas desorption index method of Coal Auger[J]. Coal mine safety 2007,38(7): 18 20.

[6] Gui Hongwei.Gas occurrence regularity and controlling factors[J]. Technology research 2015(9): 118 120.

[7] Zhang Zixu, Yuan Chongfu.Prediction of gas emission in coal mine by gas geology mathematical model[J]. Chinese Journal of coal 1999,(4): 368 373.

[8] Yi Weixin.Analysis and prediction of geological factors of coal bed methane content[J]. Zhongzhou coal, 2007,(1): 71 73.

[9] Wu Caifang, Zeng Yong.Prediction of gas content based on genetic neural network [J]. to study frontier, 2003,10(1): 219 223.

[10]Li Bentao, Li Jiakuan, Guo Caifeng. Occurrence law of coal seam gas in coal mine and its control measures in Qishan[J]. Coal science and technology, 2005,(1): 51 53. 